OmniAkuatika, $13(1): 5-12,2017$
ISSN: 1858-3873 print / 2476-9347 online
Research Article

\title{
The Study of Flow Resulting from Wave on Lhonga Beach, Aceh Besar
}

\author{
Muhammad Irham*), Ichsan Setiawan \\ Fakultas Kelautan dan Perikanan, Universitas Syiah Kuala, Banda Aceh 23111, Indonesia \\ *)corresponding author: irham@unsyiah.ac.id
}

Received 06 Februari 2017; Accepted 22 April 2017; Available online 25 May 2017

\begin{abstract}
Dynamic interaction between waves and topographic generate flow dynamics that affect Lhonga coast, Aceh Besar. To analyze the dynamics, the numerical model of currents induced by wave was developed with the explicit finite difference approach method. The model in this study was tested by verifying the result directly with the field data obtained previously. The model is applied in Lhoknga coast of Aceh Besar district with the aim to study how the dynamics of hydro-oceanography as one of the elements to support the preservation of the marine resources of the area. Based on the simulation, the results obtained that the wave occurred in Lhoknga beach relatively small with the dominant direction to the northwest and the maximum of wave height occurs during the high tide condition. The result also informed that the distribution of longshore currents is generally moving from west to east along the coast. The direction of dominant current occurs in the area of 10-15 meters from the shore with an average depth of 6 meters.
\end{abstract}

Keywords: wave flow, flow dynamics, beach, hydro-oceanography

\section{Introduction}

Sea and coastal area play an important role in supporting human life, such as the utilization of marine resources as a source of food, medical supplies, recreation and transportation. Along with efforts to harness and utilize marine resources, with due regard to the carrying capacity and environmental sustainability, the knowledge and technology and the importance of marine research should be improved. Therefore, research on marine over recent decades has become more underway which aims to support the use and preservation of the sea and coastal area.

Beside the sea, the beach as part of the coast, which is component of sea-related land, becomes the object of research and develops equally important with other marine components. Beach as a boundary between ocean and land is always changing dynamically both space and time (Eckman et al., 2008; Anoop and Kumar, 2014). These dynamic processes are influenced by a combination of several forces acting on the shore such as tides, wind, topography and geographical conditions (Rizal et al., 2013). The dynamics of tides create dynamic tidal currents, wind initiates high and low waves, and topographic and geographic conditions result in beach dynamics (Chen and Yuan, 2015), all of which are interesting to study.

The Coast of Lhoknga, Aceh Besar (Figure 1.) has unique characteristics of beach dynamic because of it is located in the region of Indian Ocean and the Strait of Malacca. However, the dominant factor the dynamics of Lhoknga beach is longshore currents that initiate sediment transport. The longshore currents are generated by surface waves that interact with topographic of the beach (Kang et al., 2015). Interaction between topographic and surface wind need to be studied because Lhoknga beach is not only a tourist area but also the area of discharging ports to support the cement industry in Aceh Besar. Therefore, the purpose of this study is to observe the effect of waves on the Lhoknga beach toward the dynamics of longshore current in the context of region marine conservation. 


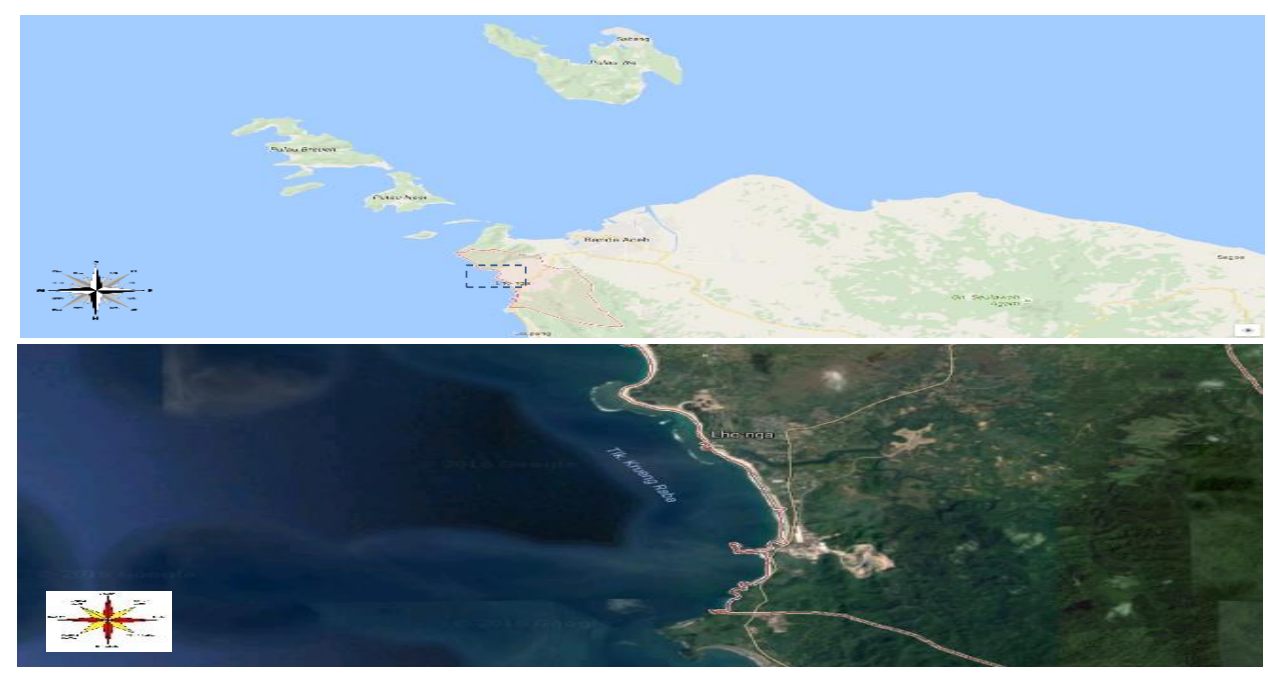

Figure 1. Study area location, Lhoknga beach Aceh Besar (no scale, Google Maps ${ }^{\mathrm{R}}$ ).

\section{Wave in a coast region}

The ocean waves occurs because of a disturbance outside the sea surface, such as wind, an earthquake under the sea, the movement of the ship, and the pull of celestial bodies. Waves from various sources, it has a different height and wave period and mutually superposed between one and the other. Waves generated by winds occur due to transport energy from the wind to the sea surface (Bunya et al., 2010). From the area of disturbance, the waves will propagate horizontally on the surface of the water in all directions leading to the beach.

Waves that occur on the surface of the ocean is not as ideal sine and cosine waves as described in simple mathematical equation, but the shapes are very complex and non-linear (McCabe et al., 2013; Badley et al., 2016). As a result of a complex nature of waves, it is a challenging to describe mathematically analytic (Sujantoko and Natakusumah, 2003). Some theories only describe simple waveforms to perform simplifications. Therefore, in this study, we used numerical model approach to obtain the information on the characteristics of the actual waves.

In the deep water, bathymetry does not affect the movement of the waves. In contrast to the events in the area of shallow water, the beach slope, the bed roughness and bed materials will affect the wave motion (Setiawan, 2009; (direction, elevation, and period). The flow pattern was calculated based on hydrodynamic equation for shallow water and the wave was calculated based on the equation of wave field distribution. The calculated results based on the
Saravanan and Chandrasekar, 2015; Irham, 2016). As a result, waves will transform their parameters and directions of propagation. This transformation process results in shoaling and causes refraction of waves (Irham et al., 2002). However, if there is a beach barrier to prevent incoming waves, the wave transformation processes effects the diffraction and reflection of waves (Mi et al., 2015).

\section{Methods and analysis}

The hydro-oceanographic of wave elevation and wave period measurement in this study ware conducted at four points (Figure 2). The four points measurement directed during the field study used purposive sampling method. Measurements were made twice in accordance with the manual measurement using stick pole and recorder. The measurement time was during high tide and low tide for duration of a month. The direction and speed of currents measurement were done at the same point with the floating ball position method. The main purpose of hydro oceanographic data collection on this occasion is to obtain the pattern of marine hydrodynamics as well as to be used for data verification purpose.

The data for oceanographic parameters in this study are bathymetry, flow patterns caused by waves (direction and magnitude), and waves mathematical equations were verified with primary data taken from the field and the secondary data obtained from BMKG (Meteorological, Climatology and Geophysics Board). 


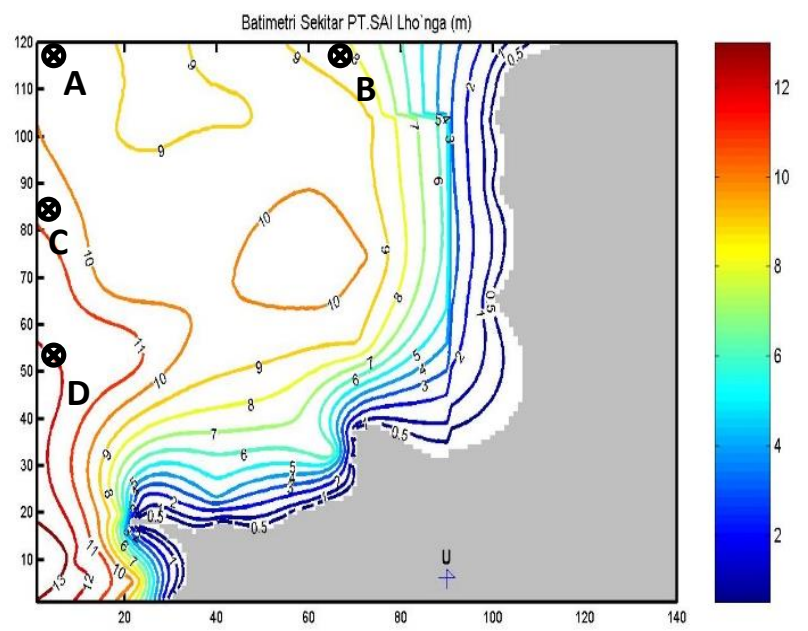

Figure 2. The bathymetry of Lhoknga beach, Aceh Besar ( @measure point).

To perform the analysis, two-dimensional numerical model was applied. The model was conservation of mass and momentum equation formula derived from depth average integration technique for shallow water dynamic. Mathematically, the formula for such model can be written as (Koutitas, 1988):

$$
\frac{\partial \bar{u}}{\partial t}+\bar{u} \frac{\partial \bar{u}}{\partial x}+\bar{v} \frac{\partial \bar{u}}{\partial y}=-g \frac{\partial \zeta}{\partial x}-\frac{C_{f} \bar{u} \sqrt{\bar{u}^{2}+\bar{v}^{2}}}{(h+\zeta)}+R_{x}+M_{x}
$$$$
\frac{\partial \bar{v}}{\partial t}+\bar{u} \frac{\partial \bar{v}}{\partial x}+\bar{v} \frac{\partial \bar{v}}{\partial y}=-g \frac{\partial \zeta}{\partial y}-\frac{C_{f} \bar{v} \sqrt{\bar{u}^{2}+\bar{v}^{2}}}{(h+\zeta)}+R_{y}+M_{y}
$$$$
\frac{\partial \zeta}{\partial t}+\frac{\partial(\bar{u}(h+\zeta))}{\partial x}+\frac{\partial(\bar{v}(h+\zeta))}{\partial y}=0
$$

where $\mathrm{t}$ is time, $(\mathrm{x}, \mathrm{y})$ are cartesian coordinates for horizontal directions, $(\bar{u}, \bar{v})$ are the average of $\mathrm{x}$ and $\mathrm{y}$ flow, $\left(R_{x}, R_{y}\right)$ are radiation stresses in the $\mathrm{x}$ and $\mathrm{y}$ directions, $\left(C_{f}\right)$ is the coefficient of friction at the base, $\zeta$ is the water surface elevation, $h$ is the depth of water, and $g$ is the gravitational acceleration. For the changes of the momentum due to turbulence flow influenced by wave forces beyond the area of breaking waves, the lateral equation can be written as follows (Horikawa 1988):

$$
M_{x}=\frac{\partial}{\partial x}\left(\varepsilon \frac{\partial \bar{u}}{\partial x}\right)+\frac{\partial}{\partial y}\left(\varepsilon \frac{\partial \bar{u}}{\partial y}\right)
$$

$$
M_{y}=\frac{\partial}{\partial x}\left(\varepsilon \frac{\partial \bar{v}}{\partial x}\right)+\frac{\partial}{\partial y}\left(\varepsilon \frac{\partial \bar{v}}{\partial y}\right)
$$

With $\varepsilon=N l \sqrt{g(h+\zeta)}$ based on LonguetHiggins (1970)

$\mathrm{N}=$ a constant number less than 0.016

$\mathrm{I}=$ distance to offshore $=(h+\zeta) / \tan \beta$

$\tan \beta=$ base slope

For the irregular bottom slope, the lateral mixing are:

$$
\begin{aligned}
& M_{x}=A_{H}\left(\frac{\partial^{2} \bar{u}}{\partial x^{2}}+\frac{\partial^{2} \bar{u}}{\partial y^{2}}\right) \\
& M_{y}=A_{H}\left(\frac{\partial^{2} \bar{v}}{\partial x^{2}}+\frac{\partial^{2} \bar{v}}{\partial y^{2}}\right)
\end{aligned}
$$

where $A_{H}$ is the horizontal viscosity coefficient.

If the waves coming at an angle against the coastline moving toward the coast, then by van Rijn (1990) the radiation of wave forces can be written as follows:

$$
\begin{aligned}
& S_{x x}=\frac{\bar{E}}{2}(2 n-1)+\bar{E} n \cos ^{2} \theta \\
& S_{y y}=\frac{\bar{E}}{2}(2 n-1)+\bar{E} n \sin ^{2} \theta \\
& S_{x y}=\frac{\bar{E}}{2} n \sin 2 \theta
\end{aligned}
$$

With $\bar{E}$ is $\frac{1}{8} \rho g H^{2}$. The momentum flux due to the presence of wave propagation can be 
defined as radiation stress components $\left(R_{x}\right.$ and $\left.R_{y}\right)$. These momentum components occur because of the water particle velocity factor triggered by the movement of waves and pressure force. While the forces that cause longshore currents are proportional to the radiation stress gradients (Longuet-Higgins, 1970) and can be written as:

$$
R_{x}=\frac{1}{\rho(d+\bar{\eta})}\left(\frac{\partial S_{x x}}{\partial x}+\frac{\partial S_{x y}}{\partial y}\right)
$$

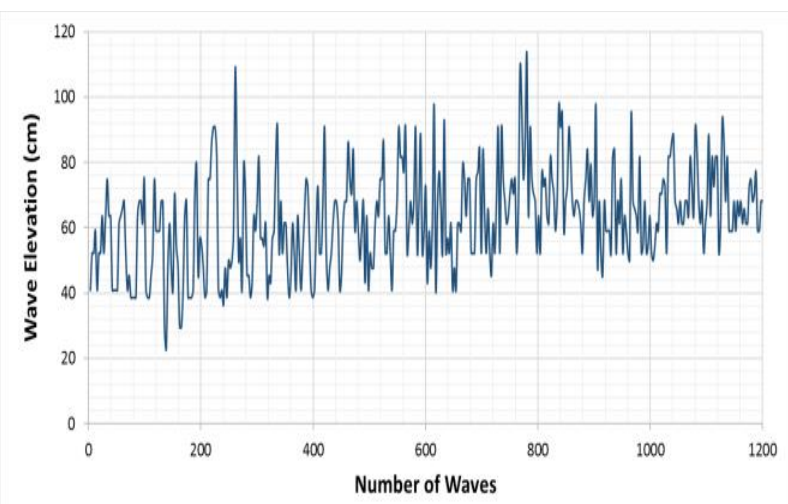

$$
R_{y}=\frac{1}{\rho(d+\bar{\eta})}\left(\frac{\partial S_{x y}}{\partial x}+\frac{\partial S_{y y}}{\partial y}\right)
$$

\section{Result and Discussion}

Field measurement at left corner point (point A) on Figure 2 of wave elevation and wave period taken during the high tide and low tide condition are shown on Figure 3 and 4 respectively. The number of data taken was about 1200 waves which are used as an initial single average number value of each for running model.

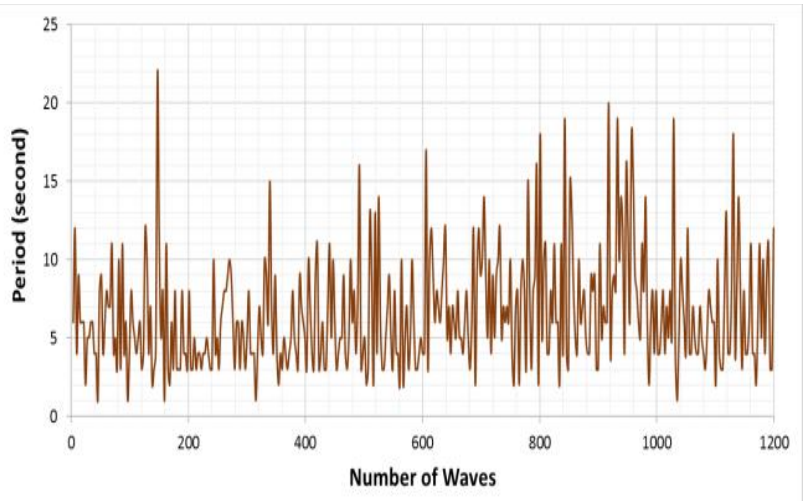

Figure 3. The profile of wave and period out of 1200 number of waves taken in field during high tide condition. The average of the waves high $(0.67 \mathrm{~m})$ and wave periods $(6$ second) are used as initial input condition in the numerical model in this study.
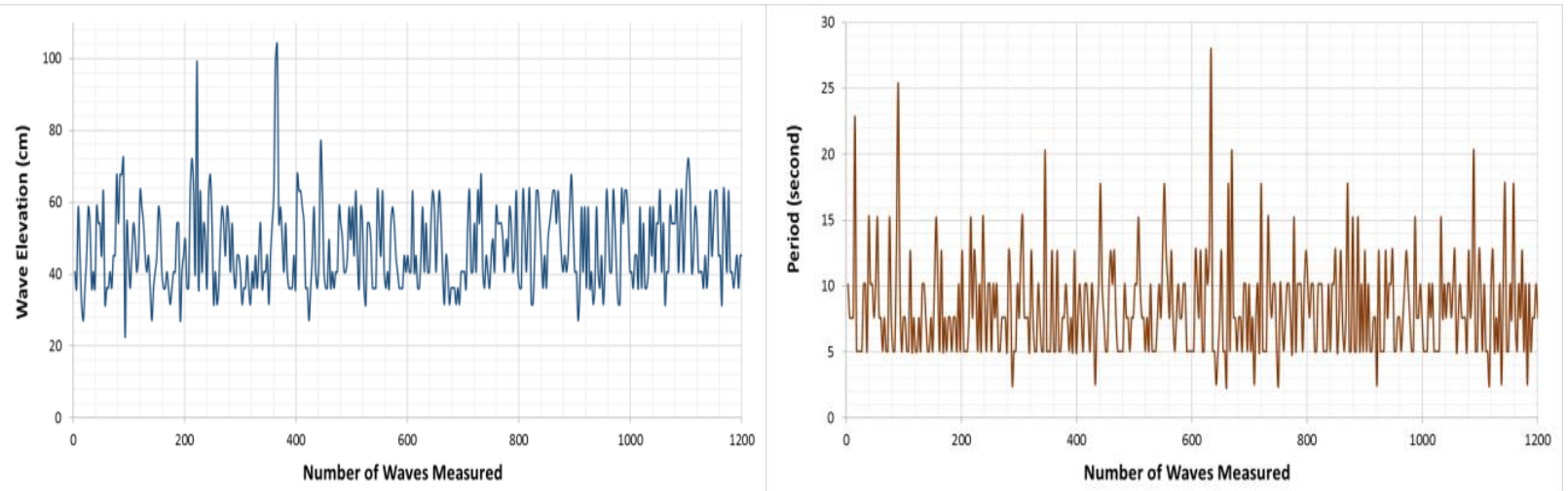

Figure 4. The profile of wave and period out of 1200 number of waves taken in field during low tide condition. The average of the waves $(0.47 \mathrm{~m})$ and period $(8$ second) are used as initial input condition in the numerical model in this study. 
Table 1.Verification points from numerical model to field measurement.

\begin{tabular}{|c|c|c|c|c|c|c|c|}
\hline \multicolumn{8}{|c|}{ During high tide condition } \\
\hline No. & & \multicolumn{3}{|c|}{ Field data measurement } & \multicolumn{3}{|c|}{ Result from model } \\
\hline 1. & Location & Point B & Point C & Point D & Point B & Point C & Point D \\
\hline 2. & Wave height & $0.5 \mathrm{~m}$ & $0.5 \mathrm{~m}$ & $0.4 \mathrm{~m}$ & $0.43 \mathrm{~m}$ & $0.46 \mathrm{~m}$ & $0.42 \mathrm{~m}$ \\
\hline 3. & current & $0.12 \mathrm{~m} / \mathrm{s}$ & $0.05 \mathrm{~m} / \mathrm{s}$ & $0.15 \mathrm{~m} / \mathrm{s}$ & $0.09 \mathrm{~m} / \mathrm{s}$ & $0.06 \mathrm{~m} / \mathrm{s}$ & $0.12 \mathrm{~m} / \mathrm{s}$ \\
\hline \multicolumn{8}{|c|}{ During low tide condition } \\
\hline No. & & \multicolumn{3}{|c|}{ Field data measurement } & \multicolumn{3}{|c|}{ Result from model } \\
\hline 4. & Location & Point B & Point C & Point D & Point B & Point C & Point D \\
\hline 5. & Wave height & $0.5 \mathrm{~m}$ & $0.5 \mathrm{~m}$ & $0.4 \mathrm{~m}$ & $0.48 \mathrm{~m}$ & $0.53 \mathrm{~m}$ & $0.51 \mathrm{~m}$ \\
\hline 6. & current & $0.07 \mathrm{~m} / \mathrm{s}$ & $0.05 \mathrm{~m} / \mathrm{s}$ & $0.11 \mathrm{~m} / \mathrm{s}$ & $0.06 \mathrm{~m} / \mathrm{s}$ & $0.03 \mathrm{~m} / \mathrm{s}$ & $0.08 \mathrm{~m} / \mathrm{s}$ \\
\hline
\end{tabular}

To ensure that the model is valid and can be analyzed, the result of wave high and current from model are saved at the same point (Figure 2 point $B, C$, and $D$ ) in the certain time. The data from model then verified to the filed data taken at the same point and time. The verification model is shown in the Table 1.

Based on the field measurement result, over all, the Lhoknga water has generally had small wave high compare to other Aceh coastal area (BMKG). Average of wave high at high tide is $0.62 \mathrm{~cm}$ with a period of 6 seconds, while at low tide, the wave high is 0.47 with a duration of 8 seconds. The small wave distribution in this area is effected by topographic of Lhoknga beach located in the bay area where the southern and western shore is an area of high plateaus and mountains. These high areas block the surface of wind waves around the beach and the plateau serves as a function of barrier of wind waves to move towards South West.

The calculated results of the wave high distribution are shown in Figure 5 and 6. Wave profile at low tide condition has average height of
$0.4 \mathrm{~m}$ with duration of 6 seconds (Figure 5 ). In the other hand, at a high tide, the average of wave height is $0.5 \mathrm{~m}$ with duration of 8 seconds (Figure 6 ). These results indicate that the distribution of wave height in this area can be considered relatively small and parallel to an uneven topographical profile of the coast. The dominant direction of wave propagation occurs around $330^{\circ}$ of North (Northwestern area) to the southeastern area, meanwhile the direction of wave propagation from Southwestern is consider small to be analyzed. Topographically, Lhoknga beach in the South and Southwest is a mountainous area immediately adjacent to the sea, thus inhibiting the movement of the waves towards the North and Northeast.

In addition to the topographic factor, wave propagation in Lhoknga beach is also influenced by the shallow depth profile (Figure 2). The slope of the bathymetry (the slope of the beach) is around 0.06 towards the West and the depth of the boundary study in the western part has average $11 \mathrm{~m}$ lead the propagation wave to follow the rhythmic of bathymetry profile. 


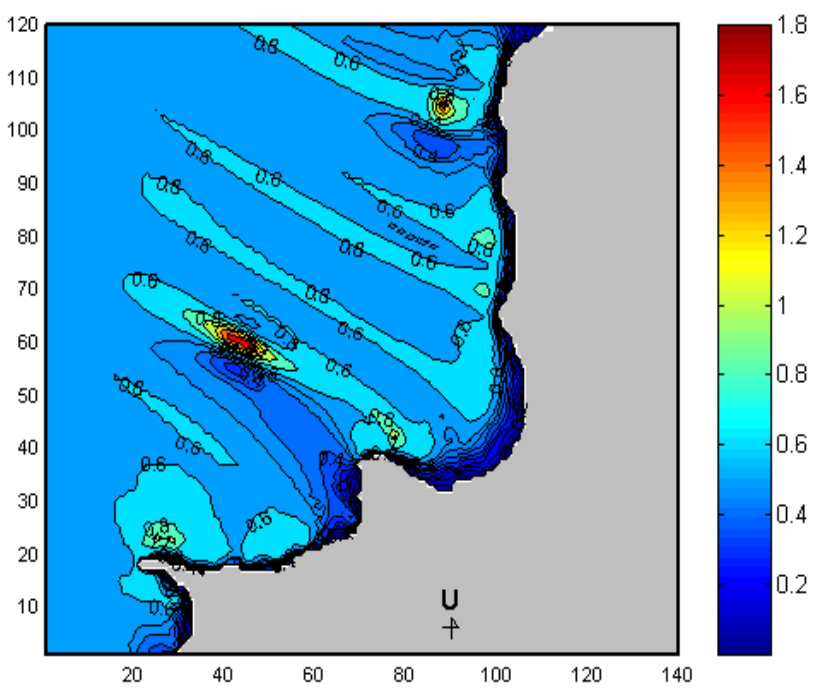

Figure 5. Wave high distribution profile at Lhoknga water during high tide condition.

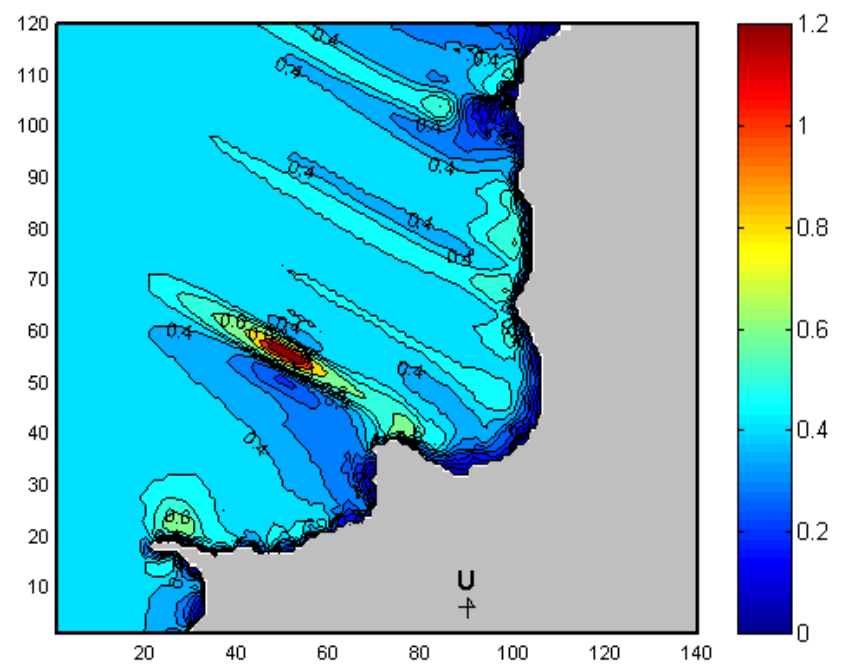

Figure 6. Wave high distribution profile at Lhoknga water during high tide condition.

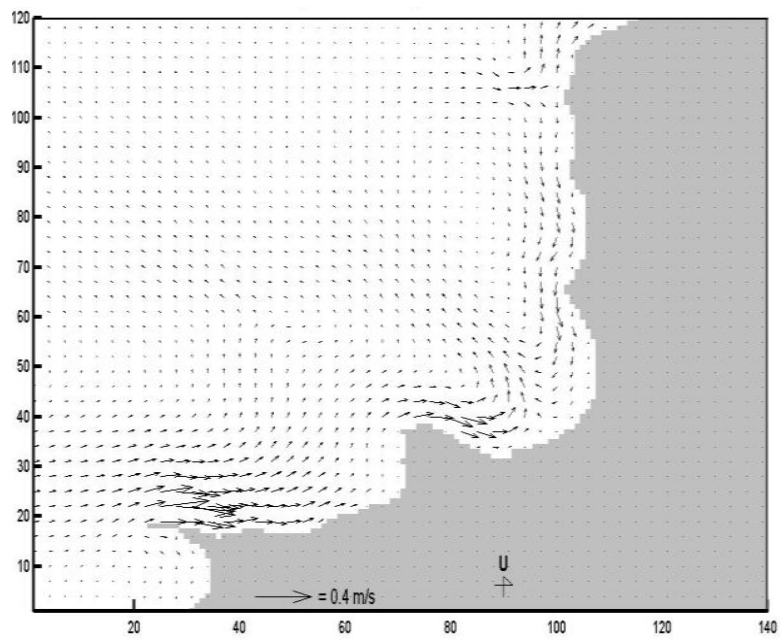

Figure 7. The profile of flow caused by wave at high tide condition. 


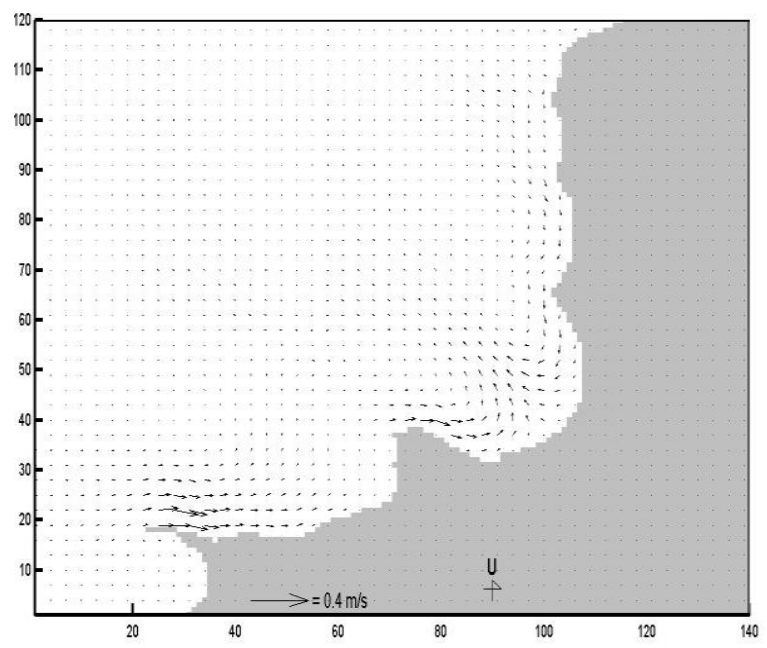

Figure 8. The profile of flow caused by wave at low tide condition.

Flow analysis caused by waves on two conditions of high and low tides is shown in Figures 7 and 8 . The results of the model indicate that the maximum speed occurs when the wave is about to break. The pattern of currents show almost the same results, either at high or low tide condition, yet the stronger currents occurs at high tide condition than low tide condition followed the pattern of wave height distribution. In the area above the depth of 6 meters, the occurrence of flow is very small compared to the flow in the area at a depth of between 4 to 6 meters. The dominant flow is occurred at a depth of 5 meters at a distance of about 15 meters from the beach.

The results show that the pattern of dominant current distribution is a longshore currents moving from the West to the East and from the South to the North of eastern beach with a maximum flow of $0.17 \mathrm{~m} / \mathrm{s}$ at low tide and 0.42 $\mathrm{m} / \mathrm{sec}$ at high tide. From the results, the visible rip currents occur at the bay area around the point of $\mathrm{x}=95 \mathrm{~m}$ and $\mathrm{y}=40 \mathrm{~m}$. As discussed before about the profile of wave distribution, the current pattern of Lhoknga beach is also influenced by the bathymetric and topographic pattern. The rhythmic of Lhoknga beach bathymetry is a factor of rip currents emergence. This rip current occurs because the accumulation of water mass in the small shallow bay after breaking waves. The mass of water crashes onto the beach and turn into backflow (feeder current) because the water masses will find loopholes to move back towards the sea. This current is faster than the current towards the shore due to reverse flow gap through a narrow channel-like with a large volume of water masses.

\section{Conclusions and Recommendations}

The results showed that the distribution of wave height in the study area is different at the condition of high tide and low tide. The wave high resulted during high tide is higher than during low tide condition. The same thing happens for the state of flow configuration. The current distribution patterns show the same profile as wave direction either throughout high tide or low tide. Based on the research results, it is expected to conduct further more research for the development and preservation of beaches in the area of Lhokga in order to have a sustainable and environmentally sound development.

\section{References}

Anoop, T.R., and Kumar, V.S. 2014. Spatial and Temporal Variation of Surface waves in Shallow Waters along the Eastern Arabian Sea. Ocean Engineering 81: 150-157

Badley, M., Wan, I., Lynch, J.F. 2016. Statistics of Nonlinear Internal Wave during the Shallow Water 2006 Experiment. Journal of Atmospheric and Oceanic Technology 33 (4): 839-846.

BMKG. 2016. Prakiraan Tinggi Gelombang dan Potensi Hujan 24-jam. http://maritim.bmkg.go.id/prakiraan. 
Bunya, S., Dietrich, J.C., Westerink, J.J., Ebersole, B.A., Smith, J.M., Atkinson, J.H., Jensen, R., Resio, D.T., Luettich, R.A., Dawson, C., Cardone, V.J., Cox, A.T., Powell, M.D.H., Westerink, J., and Roberts, H.J. 2010. A High-Resolution Coupled Riverine Flow, Tide, Wind, Wind Wave, and Storm Surge Model for Southern Louisiana and Mississippi. Part I: Model Development and Validation. Monthly Weather Review 138 (2): 345-377.

Chen, H. and Yuan, H. 2015. Study on the Influence of Coastal Change in Hydrodynamic Force and Tidal Prism of Tianjin Offshore Area. Matec Web of Converences 25.

Eckman, J.M., Andress, M.S., Marinelli, R.I., Bowlin, E., Reid, R.P., Aspden, R.J., and Paterson, D.M. 2008. Wave and Sediment Dynamic along a Shallow Subtidal Sandy Beach Inhabited by Modern Stromatolites. Geobiology 6: 21-32.

Horikawa, K. 1988. Nearshore Dynamics and Coastal Processes. University of Tokyo Press.

Irham, M., Marwan, Andonowati. 2002. Effect of Bottom Stress on Run Up of Waves. Proc. ITB 34 (1): 47-60.

Irham, M. 2016. The Spatial Distribution of Bed Sediment on Fluvial System: A Mini Review of the Aceh Meandering River. Aceh International Journal of Science and Technology 5 (2): 82-87.

Kang, S., Hun, W., and Soo, S. 2015. Characteristic of Surface Topography Variation on the Gochang Beach, Southwestern Coast of Korea. Journal of Korean Earth Science Society 6: 533-542.

Koutitas, C.G. 1988. Mathematical Models in Coastal Engineering. Pentech Press Limited, London.

McCabe, M.V., Stansby, P.K., Apsley, D.D. 2013. Random Wave Run Up and Overtopping a Steep Sea Wall: Shallow-Water and Boussinesq Modelling with Generallised Breaking and Wall Impact Algoritms Validated Angaint Laboratory and Field Measurements. Journal of Coastal Engineering 74: 33-49.

Mi, B., Xia, J., Xu, Y. 2015. Finite-difference Modeling of $\mathrm{SH}$-wave Conversions in
Shallow Shear-Wave Refraction Surveying. Journal of Applied Geophysics 119: 71-78.

Longuet-Higgins, M.S. 1970. On the Longshore Currents generated by Obliquely Incident Sea Wave - part 2. Journal of Geophysical Research 75: 6790-6801.

Saravanan, S., and Chandrasekar, N. 2015. Wave Refraction Pattern and Littoral Sediment Transport along the SE Tamilnadu Coast, India. Journal of Coastal Research 31 (2): 291- 298.

Setiawan, I. 2009. Validasi Model Numerik Arus Sejajar Pantai Dengan Model Analitik Longuet-Higgins. Dinamika Teknik Sipil 9 (1), 76-83.

Sujantoko dan Natakusumah, D.K. 2003. Model Simulasi Interaksi Gelombang dan Arus di Perairan Dangkal. Jurnal Teknik Sipil, ITB. 10 (5): 99-108.

Rizal, S., H.A. Haridhi, C.R. Wilson, A. Hasan, and I. Setiawan. 2013. Community Collection of Ocean Current Data: an Example from Northern Aceh Province, Indonesia. SPC Trad. Mar. Res. Management and Knowledge Information Bulletin 31: 3-11.

van Rijn, L.C. 1990. Principles of Fluid Flow and Surface Waves in Rivers, Estuaries, Seas, and Oceans. University of Utrecht, Department of Physical Geography. 